\title{
WW Domain-Containing Oxidoreductase
}

National Cancer Institute

\section{Source}

National Cancer Institute. WW Domain-Containing Oxidoreductase. NCI Thesaurus. Code C131550.

WW domain-containing oxidoreductase ( $414 \mathrm{aa}, \sim 47 \mathrm{kDa}$ ) is encoded by the human WWOX gene. This protein plays a role in apoptosis, oxidation/reduction and tumor suppression. 